\title{
Peran Penting Metode Takhrij dalam Studi Kehujjahan Hadis
}

\author{
Arif Maulana \\ Department of Hadith Science, Faculty of Usuluddin \\ UIN Sunan Gunung Djati Bandung \\ maulanaarip576@gmail.com
}

\begin{abstract}
The purpose of this study is to discuss the important role of the takhrij hadith method in the study of the authenticity of the hadith. This research method uses a qualitative approach with an analytical descriptive method, namely a fact-finding method with proper description and analysis of the data studied, including a general understanding of takhrij hadith, various methods of takhrij hadith, as well as the purpose and benefits of takhrij hadith. From this research, it can be concluded that takhrij hadith is the result of the efforts of previous scholars in developing the study of hadith science which is also part of the intellectual and scientific treasures that must be passed on by subsequent generations so that it continues to be maintained and developed. This research is expected to provide benefits and benefits for the treasures of Islamic scholarship.
\end{abstract}

Keywords: Hadith Science, Method, Takhrij

\begin{abstract}
Abstrak
Tujuan penelitian ini untuk membahas peran penting metode takhrij hadis dalam studi kehujjahan hadis. Metode penelitian ini menggunakan jenis pendekatan kualitatif dengan metode deskriptif analitik, yakni metode pencarian fakta dengan penggambaran dan analisis yang tepat terhadap data yang diteliti, meliputi pengertian umum tentang takhrij hadis, macam-macam metode takhrij hadis, serta tujuan dan manfaat adanya takhrij hadis. Dari penelitian ini dapat diambil kesimpulan bahwa takhrij hadis merupakan hasil dari usaha ulama terdahulu dalam mengembangkan studi ilmu hadis yang juga merupakan bagian dari khazanah intelektual dan keilmuan yang wajib diteruskan oleh generasi-generasi selanjutnya supaya terus terjaga dan berkembang. Penelitian ini diharapkan dapat memberi faedah dan manfaat bagi khazanah keilmuan Islam.
\end{abstract}

Kata kunci: Ilmu Hadis, Metode, Takhrij 
Jurnal Riset Agama, Volume 1, Nomor 1 (April 2021): 233-246

Arif Maulana/Peran Penting Metode Takhrij dalam Studi Kehujjahan Hadis

\section{Pendahuluan}

Hadis adalah segala yang diberitakan bersumber dari Nabi SAW baik berupa sabda, perbuatan, taqrir, sifat-sifat maupun hal ikhwal yang menyertai Nabi (Al-Khatib, 1975). Pembahasan tentang kehujjahan hadis meliputi nilai atau kualitas hadis dan pengamalan hadis. Kualitas hadis ada yang maqbul (diterima) dan mardud (ditolak), sehingga perlu dilakukan penelitian lebih lanjut mengenai hadis tersebut yakni dengan cara takhrij hadis (Ash-Shiddieqy, 1967). Takhrij hadis adalah penunjukkan terhadap tempat hadis dalam sumber-sumber aslinya yang dijelaskan sanadnya dan martabatnya sesuai dengan keperluan (Al-Thahhan, 1982). Takhrij meliputi kegiatan periwayatan, penukilan, pengutipan, dan pembahasan hadis. Adapun cara mentakhrij hadis terbagi menjadi tiga, yaitu metode takhrij atau al-Naql, takhrij dengan tashih, takhrij dengan $i^{\prime}$ tibar. Proses takhrij hadis tidak sebatas hanya pada matan hadis saja, melainkan juga meliputi takhrij matan hadis dari berbagai kitab induk, mentakhrij sanad hadis beserta biografi dan penilaian tentang para perawinya (Soetari, 1997).

Sejumlah ahli telah melakukan penelitian yang berkenaan dengan studi takhrij hadis sebagaimana yang terdapat pada tinjauan pustaka penelitian ini. Antara lain Sanusi, Ahmad (2014), “Takhrij Hadis," Penerbit UIN Sultan Maulana Hasanuddin. Artikel ini menggunakan metode kajian kepustakaan. Hasil pembahasan artikel ini menyatakan bahwa kebutuhan takhrij dirasa sangat perlu karena masalah takhrij hadis ini sangat dibutuhkan setiap orang yang menekuni ilmu-ilmu syariat dan yang sehubungan dengannya. Artikel ini menyimpulkan bahwa mengetahui masalah takhrij dan metodenya adalah sesuatu yang sangat penting bagi orang yang mempelajari ilmu-ilmu syariat agar mampu melacak suatu hadis sampai pada sumbernya (Sanusi, 2014). Rabbani, Lubis. (2019) "Ilmu Takhrij Hadis dalam Sorotan," Penerbit Jurnal Universum IAIN Kediri. Artikel ini menggunakan metode penelitian kualitatif. Hasil pembahasan artikel ini menyatakan gambaran penting yang disorot mengenai perkembangan penggambaran teori dan praktik dalam ilmu takhrij hadis. Artikel ini menyimpulkan bahwa takhrij hadis memang sudah dilakukan oleh ulama terdahulu dengan metodenya masing-masing, namun dewasa ini perkembangan dan penggambaran takhrij hadis sudah mulai menyasar pada metode digitalisasi berbentuk online, software atau aplikasi (Lubis, 2019). Qomarullah, Muhammad. (2016), "Metode Takhrij Hadis dalam Menakar Hadis Nabi," Penerbit Jurnal Studi Keislaman STAI Bumi Silampari. Artikel ini menggunakan metode penelitian library research. Hasil pembahasan artikel ini menyatakan bahwa takhrij hadis merupakan salah satu metode (cara) untuk mengetahui asal-usul riwayat hadis yang akan diteliti. Artikel ini menyimpulkan bahwa urgensi takhrij hadis dalam mengkaji hadis juga untuk memberikan kemudahan bagi orang yang ingin mengamalkan setelah mengetahui hadis yang menjadi hadis maqbul 
Jurnal Riset Agama, Volume 1, Nomor 1 (April 2021): 233-246

Arif Maulana/Peran Penting Metode Takhrij dalam Studi Kehujjahan Hadis

(diterima), dan sebaliknya tidak mengamalkan hadis yang menjadi mardud (ditolak) (Qomarullah, 2016).

Berbagai penelitian terdahulu sangat berharga dalam penyusunan kerangka berpikir penelitian ini. Cara untuk menentukan kesahihan suatu hadis adalah dengan menggunakan kaidah keshahihan dan atas dasar petunjuk literatur yang disebut tashih dan i'tibar. Jika dikaji lebih lanjut, petunjuk tersebut dapat dirumuskan sebagai metode takhrij hadis. Takhrij hadis merupakan salah satu metode (cara) untuk mengetahui asal-usul riwayat hadis yang akan diteliti, meliputi periwayatan, penukilan, pengutipan, dan pembahasan (Soetari, 1997). Kebutuhan takhrij hadis dirasa sangat perlu karena orang yang mempelajari hadis tidak akan dapat membuktikan atau tidak dapat meriwayatkannya, kecuali setelah ulamaulama yang telah meriwayatkan hadis dalam kitabnya dengan dilengkapi sanadnya. Karena itu, masalah takhrij hadis ini sangat dibutuhkan setiap orang yang menekuni ilmu-ilmu syariat dan yang sehubungan dengannya (Sanusi, 2014).

Berdasarkan paparan di atas, penulis mencoba menyusun formula penelitian, yaitu rumusan masalah, pertanyaan penelitian, dan tujuan penelitian (Darmalaksana, 2020). Rumusan masalah penelitian ini adalah terdapat peran penting metode takhrij dalam studi kehujjahan hadis. Pertanyaan penelitian ini adalah bagaimana peran penting metode takhrij dalam studi kehujjahan hadis. Tujuan penelitian ini adalah untuk membahas peran penting metode takhrij dalam studi kehujjahan hadis.

\section{Metode Penelitian}

Metode penelitian yang digunakan oleh penulis dalam karya ilmiah ini adalah menggunakan pendekatan kualitatif. Metode kualitatif selalu berusaha memberi pemahaman dan penafsiran makna suatu obyek tertentu berdasarkan standar yang telah ditentukan. Penelitian kualitatif bertujuan untuk menjelaskan dengan sedalam-dalamnya terkait nilai dan kualitas suatu obyek yang diteliti melalui pengumpulan data (Gunawan, 2013).

Penulis juga menggunakan metode deskriptif analitik, yakni metode pencarian fakta dengan penggambaran dan analisis yang tepat terhadap data yang diteliti, sehingga jenis penelitan yang tepat dalam karya ilmiah ini adalah penelitian studi kasus. Studi kasus adalah penjelasan dan uraian yang komprehensif terkait berbagai fenomena yang ditemukan dalam pengumpulan dan penelitian data. Kelebihan dari metode studi kasus adalah penelitiannya yang dilakukan secara terperinci, intensif, dan mendalam terhadap objek penelitian (Fitrah \& Luthfiyah, 2017).

\section{Hasil dan Pembahasan Penelitian}

Hasil dan pembahasan penelitian di bawah ini. 
Jurnal Riset Agama, Volume 1, Nomor 1 (April 2021): 233-246

Arif Maulana/Peran Penting Metode Takhrij dalam Studi Kehujjahan Hadis

\section{Pengertian Umum tentang Takhrij Hadis}

Definisi takhrij secara bahasa, berarti istinbath (mengeluarkan), tadrib (memperdalam), dan taujih (menampakkan) (Soetari, 1997). Maksudnya yaitu menampakkan sesuatu yang masih tersembunyi, mengeluarkan yang tidak terlihat dan memperdalam yang masih samar. Maksud dari pengeluaran di sini tidak harus berbentuk fisik secara nyata, tetapi mencakup nonfisik yang cukup menggunakan pikiran, seperti makna kata istikhraj yang mempunyai kesamaan dengan kata istinbath yang artinya mengeluarkan hukum dari nash Al-qur'an dan hadis (Qomarullah, 2016).

Sedangkan menurut istilah Muhadisin, takhrij diartikan dalam beberapa pengertian, di antaranya: 1) Bentuk sinonim dari kata ikhraj, yakni seorang rawi yang mengemukakan suatu hadis dengan menyebutkan sumber keluarnya (pemberita) hadis tersebut; 2) Mengeluarkan hadis-hadis dari berbagai kitab yang kemudian disebutkan sanad-sanadnya secara lengkap; 3) Menukil hadis dari kitab-kitab induk (diwan al-hadis) dengan menyebutkan mudawinnya serta menjelaskan martabat hadisnya; 4) Menunjukkan genealogi hadis kemudian menjelaskan sumber periwayatannya dari berbagai kitab hadis yang disusun oleh orang yang men-takhrij secara langsung yang kapasitasnya sebagai penghimpun kitab hadis; dan 5) Menunjukkan letak hadis pada kitab sumber yang asli, yakni kitab yang menyebutkan sanad dan matan hadis tersebut (Lubis, 2019).

Mahmud al-Thahhan mendefinisikan takhrij sebagai berikut (AlThahhan, 1982):

$$
\text { التخرج هو الدلالة على موضع الحديث في مصادر الاصلية التي اخرجته بسنده ثم بيان مرتبته عند الحاجة }
$$

"Takhrij adalah penunjukkan terhadap tempat hadis dalam sumber-sumber aslinya yang dijelaskan sanadnya dan martabatnya sesuai dengan keperluan."

Dari paparan di atas kemudian dapat disimpulkan bahwa takhrij hadis meliputi beberapa kegiatan, di antaranya: 1) Periwayatan (penerimaan, pemeliharaan, pentadwinan, dan penyampaian) hadis; 2) Penukilan hadis dari kitab-kitab sumber untuk dihimpun dalam suatu kitab tertentu; 3) Mengutip hadis-hadis dari berbagai kitab Fan (tafsir, tajwid, fiqih, tasawuf, dan akhlak) dengan menyebutkan sanad-sanadnya secara lengkap; dan 4) Membahas hadis-hadis sampai diketahui martabat kualitas hadis, yakni dari segi maqbul (diterima) dan mardud (ditolak).

Sebelum melakukan langkah-langkah dalam melakukan takhrij hadis, hal yang paling utama adalah mengetahui metodenya agar mendapatkan kemudahan dan terhindar dari berbagai hambatan. Karena metode merupakan hal terpenting dalam tehnik bagaimana menelusuri hadis dengan mudah. Serta perlu diketahui bahwa dalam membukukan hadis, 
Jurnal Riset Agama, Volume 1, Nomor 1 (April 2021): 233-246

Arif Maulana/Peran Penting Metode Takhrij dalam Studi Kehujjahan Hadis

para ulama muhadisin terdahulu masing-masing mempunyai keragaman dan keunikan tertentu, seperti dalam pengurutannya ada yang menggunakan huruf alphabet Arab seperti pada kitab al-Jami' ash-Shaghir karya Imam as-Suyuthi. Kemudian ada juga yang menggunakan cara tematik (maudhu'i) yakni berdasar tema-tema tertentu, seperti kitab al-Jami' ash-Shahih li al-Bukhari dan sunan Abu Dawud. Metode seperti itu digunakan oleh para Ulama Muhadisin semata-mata untuk memberi kemudahan bagi orang yang membaca dan mengkajinya, terutama umat Islam (Lubis, 2019).

Beberapa kitab takhrij hadis yang terkenal, antara lain:

a. Nasb al-Rayah li Ahadis al-Hidayah li al-Marghinani, karya al-Imam alHafizh Jamaluddin Abu Muhammad Abdillah bin Yusuf al-Zaila'i alHanafi (w.762 H).

Kitab ini merupakan takhrij hadis-hadis kitab al-Hidayah, sebuah kitab fiqih madzhab Hanafi, yang disusun oleh Ali bin Abu Bakar al-Marghinani, salah seorang pemuka fuqaha Hanafi (w. $593 \mathrm{H}$ ).

Kitab ini mengungkap secara lengkap riwayat-riwayat yang penuh faidah, dan mengupas setiap hadis yang ada dalam kitab al-Hidayah, disertai riwayat dan hadis-hadis lain yang menguatkannya. Kitab ini juga mengungkapkan pembahasan mengenai hadis-hadis yang dijadikan dalil oleh para ulama yang berbeda pendapat dengan ulama Hanafiyah, secara jelas, tuntas, objektif, dan tematis.

Semua ini menunjukkan kedalaman dan penguasaan al-Zaila'i dalam bidang ilmu hadis, sehingga para ulama setelahnya mengikuti jejaknya.

b. Al-Mughni 'an Haml al-Asfar fi Takhrij Ma fi al-Ihya' min al-Akhbar, karya al-Hafizh al-Kabir al-Imam Abdurrahim bin al-Husain al-'Iraqi (w. 806 $\mathrm{H})$

Beliau merupakan guru dari al-Hafizh Ibnu Hajar. Ia adalah seorang nomor satu dalam bidang ilmu hadis pada waktu itu.

Kitab ini merupakan takhrij hadis-hadis sebuah kitab yang sangat penting dan terkenal di kalangan umat Islam, yaitu kitab Ihya' 'Ulum al-Din karya Imam al-Ghazali.

Metode penulisannya adalah dengan menyebutkan sebagian dari tiap hadis al-Ihya' lalu menjelaskan orang yang mengeluarkannya dan sahabat yang meriwayatkannya, kemudian menjelaskan kualitasnya, baik sahih, hasan, maupun dha'if.

Kitab ini dicetak menyatu dengan kitab Ihya', dan merupakan ringkasan dari takhrij yang besar dan luas yang disusunnya, dan kini tidak dapat dijumpai lagi. Al-Zubaidi menyertakan takhrij yang besar itu ke dalam syarah al-Ihya' yang disusunnya. 
Jurnal Riset Agama, Volume 1, Nomor 1 (April 2021): 233-246

Arif Maulana/Peran Penting Metode Takhrij dalam Studi Kehujjahan Hadis

c. Al-Talkhish al-Habir fi Takhrij Ahadis al-Rafi'i al-Kabir, karya Ibnu Hajar.

Kitab ini merupakan takhrij hadis-hadis al-Syarh al-Kabir karya alRafi'i, yang merupakan syarah al-Wajiz fi al-Figh al-Syafi'i karya Imam alGhazali.

Kitab ini juga merupakan kesimpulan dari kitab-kitab takhrij serupa yang telah disusun sebelumnya. Ide itu diperoleh penyusunannya setelah ia membaca Nashb al-Rayah karya al-Zaila'i.

Dengan demikian, kitab ini tampil lengkap dan mencakup keterangan-keterangan yang berserakan di dalam kitab-kitab sebelumnya.

Teknik penyusunannya adalah dengan menyebutkan sebagian cuplikan tiap hadis yang terdapat dalam al-Syarh al-Kabir kemudian menyebutkan tempatnya pada sumber-sumbernya lengkap dengan sanadsanadnya serta para rawinya, kemudian membicarakan setiap rawi dengan rinci yang menyangkut jarh dan ta'dil-nya serta kesahihan dan kedha'ifannya. Kemudian menyebutkan hadis-hadis yang semakna dengannya.

Oleh karena itu, kitab ini menjadi rujukan hadis-hadis hukum yang sama sekali tidak dapat diabaikan ('Itr, 1994).

\section{Macam-macam Metode Takhrij Hadis}

Mengambil suatu hadis dari suatu kitab, lalu mencari sanad yang lain dari sanad penyusun kitab itu sudah tentu menjadi pekerjaan yang membutuhkan ketelitian dan kecermatan yang tinggi bagi seorang peneliti hadis. Orang yang mengerjakan hal ini disebut mukharrij atau mustakhrij (Ash-Shiddieqy, Sejarah dan Pengantar Ilmu Hadits, 1980).

Berbagai cara takhrij hadis telah banyak diperkenalkan oleh para ahli hadis, di antaranya yang dikemukakan oleh Mahmud al-Thahhan yang menyebutkan lima teknik (thariqah) dalam menggunakan metode takhrij sebagai al-Naql untuk studi hadis, yakni sebagai berikut:

a. Takhrij dengan mengetahui rawi sahabat atas bantuan kitab Musnad, Mu'jam, dan 'Athaf.

b. Takhrij dengan mengetahui salah satu kalimat matan hadis atas bantuan kitab $M u^{\prime} j a m$, Fihris, dan lain-lain.

c. Takhrij dengan cara mengetahui kalimat awal matan hadis yang kurang tersebar dalam pembicaraan (kurang dikenal), atas bantuan kitab alMu'jam al-Mufahras li al-Fazh al-Hadis al-Nabawi.

d. Takhrij dengan mengetahui tema (maudhu') hadis yang berkaitan dengan sistematika dan bagian atau unsur materi agama Islam.

e. Takhrij dengan mengetahui keadaan rawi, sanad, dan matan hadis dengan bantuan kitab Musthalah (Al-Thahhan, 1982).

Berikut adalah beberapa metode takhrij hadis: 
Jurnal Riset Agama, Volume 1, Nomor 1 (April 2021): 233-246

Arif Maulana/Peran Penting Metode Takhrij dalam Studi Kehujjahan Hadis

\section{a. Metode Takhrij/al-Naql Melalui Pengetahuan tentang Nama Sahabat Perawi Hadis}

Metode ini hanya digunakan apabila nama sahabat tersebut tercantum pada hadis yang akan di-takhrij. Apabila nama sahabat tersebut tidak tercantum dalam hadis dan tidak dapat diusahakan untuk mengetahuinya, maka sudah tentu metode ini tidak dapat dipakai.

Apabila nama sahabat tercantum dalam hadis tersebut, atau tidak tercantum tetapi dapat diketahui dengan cara lain, kemudian ditentukan pula metode takhrij yang didasarkan pada pengetahuan nama sahabat, perawi hadis, maka dapat digunakan tiga macam kitab, yaitu kitab-kitab Musnad, Mu'jam, dan Athraf.

Kitab Musnad adalah kitab yang disusun berdasarkan urutan nama sahabat sesuai dengan kedahuluannya masuk Islam, atau nasabnya. Dalam kitab ini, hadis-hadis para sahabat dikumpulkan secara tersendiri.

Kitab Musnad yang ditulis oleh para ahli hadis itu jumlahnya sangat banyak. Menurut al-Thahhan, jumlahnya sekitar 100 kitab atau lebih. Sebagian diantaranya sebagai berikut: 1) Musnad Ahmad bin Hanbal; 2) Musnad Abi Bakr Sulaiman Ibn Dawud al-Thalayisi; 3) Musnad Asad Ibn Musa al-Umawi; 4) Musnad Baqi Ibn Mukhallid; dan sebagainya.

Kitab $\mathrm{Mu}^{\prime}$ jam adalah kitab yang disusun menurut nama-nama sahabat, guru, negeri atau lainnya. Dan nama-nama itu biasanya diurutkan secara alphabetis. Adapun kitab-kitab Mu'jam yang terkenal adalah: 1) alMu'jam al-Kabir li Abi al-Qasim Sulaiman Ibn Ahmad al-Thabrani; 2) al-Mu'jam al-Ausath li Abi al-Qasim Sulaiman Ibn Ahmad al-Thabrani; 3) Mu'jam alShaghir li Abi al-Qasim Sulaiman Ibn Ahmad al-Thabrani; 4) Mu'jam al-Shahabah li Ahmad Ibn al-Hamdani; 5) Mu'jam al-Shahabah li Abi Ya'la Ahmad Ibn Ali alMushili.

Kitab Athraf adalah semacam kitab hadis yang penyusunannya hanya menyebutkan sebagian matan hadis yang menunjukkan keseluruhannya. Sistematika kitab ini biasanya mengikuti Musnad sahabat, yakni secara alphabetis. Dimulai dari hadis-hadis sahabat yang namanya diawali huruf alif, kemudian $b a^{\prime}$ dan seterusnya.

Kitab Athraf ini juga memiliki jumlah yang banyak, beberapa yang terkenal antara lain: 1) Athraf al-Sahihain li Abi Mas'ud Ibrahim Ibn Muhammad al-Dimasyqi; 2) Athraf al-Sahihain li Abi Muhammad Khalaf Ibn Muhammad al-Wasithi; 3) Al-Isyraf'Ala Ma'rifat al-Athrafli Ibn Asaki; 4) Tuhfah al-Isyraf Bima'rifah al-A thraf li al-Hafizh al-Hujjaj Yusuf Abdurrahman al-Mazi.

Adapun manfaat dari kitab Athraf, antara lain:

1) Memberi informasi tentang berbagai sanad suatu hadis secara keseluruhan dalam suatu tempat. Dengan demikian dapat diketahui dengan mudah apakah hadis itu gharib, 'aziz, atau masyhur. 
Jurnal Riset Agama, Volume 1, Nomor 1 (April 2021): 233-246

Arif Maulana/Peran Penting Metode Takhrij dalam Studi Kehujjahan Hadis

2) Memberi informasi tentang siapa saja di antara para penyusun kitabkitab hadis yang meriwayatkannya dan dalam bab apa mereka cantumkan.

3) Memberi informasi tentang jumlah hadis setiap sahabat yang diriwayatkan hadisnya dalam kitab-kitab yang dibuat athraf-nya.

Mengingat kitab athraf ini hanya menyebutkan sebagian matan hadis, maka untuk mengetahui secara lengkap masih perlu merujuk kepada kitab sumber yang ditunjukkan oleh kitab athraf tersebut.

\section{b. Metode Takhrij/al-Naql Melalui Lafazh Awal dari Matan Hadis}

Metode ini dipakai apabila permulaan lafazh hadis-hadis itu dapat diketahui dengan tepat. Jenis kitab yang dipakai dengan metode ini adalah:

1) Kitab-kitab hadis yang disusun untuk hadis-hadis yang populer dalam masyarakat. Kitab-kitab ini antara lain: a) Al-Tadzkirah fi Ahadis alMusytaharah li al-Zarkasyi; b) Al-Durar al-Muntatsirah fi Ahadis alMusytaharah al-Suyuthi; c) Al-Laiy al-Mansurah fi al-Ahadis al-Masyhurah Mimma Allafahu al-Thab' wa Laisa Lahu Ashl fi al-Asyar li Ibn Hajar; d) AlMaqashid al-Hasanah fi Bayan Katsir Min al-Ahadis Musytaharah 'ala alAlsinah li al-Sakhawi.

2) Kitab hadis yang disusun secara alphabetis, antara lain, al-Jami' al-Shaghir Min Hadis al-Basyir al-Nadzir li Jalaluddin Abdurrahman Abi Bakr al-Suyuthi. Kitab tersebut berisi kirang lebih 10031 hadis, diringkas dari kitab Jam'u al-Jawami. Dalam kitab ini, hadis-hadis disusun secara alphabetis menurut permulaan lafazh hadis kemudian lafazh sesudah yang pertama (sebagaimana kamus pada umumnya) untuk memudahkan penemuan hadis. Cara penyebutan hadis pada kitab ini, mula-mula disebutkan matan hadis secara lengkap, kemudian dalam tanda kurung disebutkan perawinya. Setelah itu baru nama sahabat (tidak dalam kode) dan terakhir kode nilai hadis dalam tanda kurung.

3) Kitab-kitab kunci atau indeks bagi kitab-kitab tertentu antara lain: a) Fahras li Tartib Ahadis Shahih Muslim li Muhammad Fuad Abdul Baqi; b) Miftah li Ahadis Muwatha' Malik; c) Fahras li Tartib Ahadis Sunan Ibn Majah li Muhammad Fuad Abdul Baqi. Mengingat kitab-kitab tersebut hanya mneyebutkan tharaf (sebagian) hadis, maka untuk mengetahui teks hadis secara lengkap dapat membuka sumber aslinya dengan petunjuk yang ada.

\section{c. Metode Takhrij/al-Naql Melalui Pengetahuan Salah Satu Lafazh Hadis}


Jurnal Riset Agama, Volume 1, Nomor 1 (April 2021): 233-246

Arif Maulana/Peran Penting Metode Takhrij dalam Studi Kehujjahan Hadis

Metode ini hanya menggunakan satu kitab petunjuk saja, yaitu kitab al-mu'jam al-Mufahras li Alfazh al-Hadis al-Nabawi.

Kitab ini merupakan susunan sejumlah orientalis yang dipimpin oleh A.J. Wensink. Sedangkan dari kalangan Muslim yang ikut terlibat dalam penyusunannya adalah Muhammad Fuad Abd al-Baqi.

Kitab ini disusun hampir mrip dengan susunan kamus pada umumnya. Karena itu diperlukan pengetahuan tentang ilmu nahwu dan sharaf secara mendalam.

Kelebihan dari kitab yakni dapat mengambil kata apa saja yang kita ingat dari hadis yang akan kita takhrij, tidak harus mengetahui nama sahabat perawinya atau lafazh hadis itu secara keseluruhan sebagaimana metode-metode yang telah lalu.

Kitab-kitab hadis sumber asli yang dijadikan rujukan oleh kitab ini ada sembilan kitab, yaitu: Sahih Bukhari, Sahih Muslim, Sunan al-Turmudzi, Sunan Abu Dawud, Sunan al-Nasa'i, Sunan Ibn Majah, Muwatha' Malik, Musnad Ahmad, dan Sunan al-Darimi. Masing-masing mempunyai kode tersendiri. Di samping disebutkan sumber asli, disebutkan juga nama kitabnya (sub judul dalam kitab sumber), Kecuali Musnad Ahmad karena memakai sistem musnad. Dan disebutkan pula nomor babnya, kecuali dalam Sahih Muslim dan Muwatha' Malik yang nomornya menunjukkan nomor urut hadis. Sedangkan dalam Musnad Ahmad, nomor besar menunjukkan juz, nomor kecil menunjukkan halaman.

\section{d. Metode Takhrij/al-Naql Melalui Pengetahuan Tema Hadis}

Metode ini akan mudah digunakan bagi orang yang sudah terbiasa dan ahli dalam hadis. Orang yang awam dalam hadis akan sulit menggunakannya, karena hal yang dituntut dalam metode ini adalah kemampuan menentukan tema atau salah satu tema dari suatu hadis yang hendak ditakhrijkan. Baru kemudian kita membuka kitab hadis pada bab dan kitab yang mengandung tema tersebut. Misalnya, hadis tentang mandi junub kita cari di bab Thaharah pada kitab tertentu dan seterusnya. Dengan demikian, pada prinsipnya pen-takhrij yang menggunakan metode ini dihadapkan langsung pada kitab-kitab sumber, tampa perantara. Kecuali jika memakai kitab Miftah Kunuz al-Sunnah, pen-takhrij ditunjukkan tempat suatu hadis dalam kitab-kitab sumber.

Adapun kitab yang digunakan dalam metode ini adalah kitab-kitab yang disusun secara tematis. Kitab-kitab ini dapat dibedakan ke dalam tiga kelompok, yaitu:

1) Kitab yang berisi seluruh tema agama, yaitu kitab Jawami', berikut dengan Mustakhraj dan Mustandrak-nya, al-Majami', al-Zawa'id, dan kitab Miftah Kunuz al-Sunnah. Di antara kitab yang tergolong kelompok ini adalah: a) Al-Jami' al-Sahih li al-Bukhari; b) Al-Jami' al-Sahih li al-Muslim; c) 
Jurnal Riset Agama, Volume 1, Nomor 1 (April 2021): 233-246

Arif Maulana/Peran Penting Metode Takhrij dalam Studi Kehujjahan Hadis

Mustakhraj al-Ismaili; d) Misbah al-Zujajah fi Zawa'id Ibn Majah li alBushairi; dan yang lainnya.

2) Kitab yang berisi sebagian banyak tema-tema agama, yaitu kitab-kitab Sunan, Mushannaf, Muwaththa', dan Mustakhrajat 'ala al-Sunan. Di antara kitab yang tergolong kelompok ini adalah: a) Sunan Abi Dawud li; b) AlMushannaf al-Shan'ani; c) Al-Muwaththa' Imam Malik; d) Al-Mustakhraj 'ala Sunan Abi Dawud li Qasim Ibn Ashbagh.

3) Kitab-kitab yang berisi satu aspek saja dari tema-tema agama, yaitu kitab-kitab hadis yang berkaitan dengan hukum saja, akhlak saja, dan lainnya. Di antara kitab yang tergolong kelompok ini adalah: Al-Ahkam li Abd al-Ghani Ibn Abd al-Wahid al-Muqdisi, dan kitab Akhlak Nabi SAW li Abi al-Syaikh Abi Muhammad Abdullah Ibn Muhammad al-Ashbahani.

Sebagaimana telah disinggung sebelumnya, bahwa kitab Kunuz alSunnah secara khusus memberi petunjuk kepada pen-takhrij suatu hadis tentang di mana letak hadis itu dalam kitab-kitab sumber. Kitab ini merujuk kepada 14 sumber dengan kode-kode tertentu, yaitu:

Tabel 1. Kode-kode Sumber Kitab Hadis

\begin{tabular}{|c|c|c|c|}
\hline & : Bukhari & & : Muwaththa' Malik \\
\hline مس - مس & : Muslim & j & : Muasnad Zaid Ibn Ali \\
\hline بد & : Abu Dawud & عد & : Thabaqah Ibn Sa'ad \\
\hline تز & : Turmudzi & حم & : Musnad Ahmad \\
\hline نس & : al-Nasa'i & b & : Musnad al-Thayalisi \\
\hline مج & : Ibnu Majah & هش & : Sirah Ibn Hisyam \\
\hline 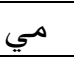 & : al-Darimi & قد & : Maghazi al-Waqidi \\
\hline
\end{tabular}

Keterangan: kode tersebut merupakan kode kitab-kitab sumber hadis. berikut:

Selain kode untuk sumber, terdapat juga kode singkatan sebagai

$$
\begin{array}{ll}
\text { s } & : \text { singkatan dari kitab } \\
ب & : \text { singkatan dari bab } \\
\tau & : \text { singkatan dari hadis } \\
\text { ص } & : \text { singkatan dari shafhah (halaman) } \\
\text { ج } & : \text { singkatan dari juz } \\
\text { ق } & : \text { singkatan dari qism (bagian) } \\
\text { قا } & : \text { singkatan dari qarin (bandingkan) }
\end{array}
$$

Hal yang perlu diperhatikan bahwa di dalam kitab ini di samping tiap-tiap tema itu diurutkan secara alphabetis, di bawah tiap-tiap tema itu dicantumkan pula potongan (tharaf) hadis-hadis yang termasuk dalam 
Jurnal Riset Agama, Volume 1, Nomor 1 (April 2021): 233-246

Arif Maulana/Peran Penting Metode Takhrij dalam Studi Kehujjahan Hadis

tema itu. Tetapi terkadang yang ditulis di bawah tema tersebut bukan potongan hadis, melainkan makna hadis itu, bahkan hanya sub temanya saja.

\section{e. Metode Takhrij Melalui Pengetahuan tentang Sifat Khusus atau Sanad Hadis itu}

Yang dimaksud dengan metode takhrij ini adalah memperhatikan keadaan-keadaan dan sifat hadis baik yang ada pada matan atau sanadnya, kemudian mencari asal hadis-hadis itu dalam kitab yang khusus mengumpulkan hadis yang mempunyai keadaan atau sifat tersebut, baik dalam matan atau sanadnya. Yang pertama diperhatikan adalah keadaan atau sifat yang ada pada matan, kemudian yang ada pada sanad dan selanjutnya yang ada pada keduanya.

\section{1) Ditinjau dari segi matan}

Apabila pada matan hadis itu nampak tanda-tanda ke-maudhu-an, baik karena rendahnya (rakakah) bahasa atau secara jelas bertentangan dengan nash al-Qur'an yang sharih, maka cara yang paling mudah untuk mengetahui asal hadis itu adalah dengan mencari dalam kitab-kitab yang mengumpulkan hadis-hadis maudhu'. Dalam kitab ini akan diterangkan dengan jelas hal tersebut. Kitab semacam ini ada yang disusun secara alphabetis, seperti kitab al-Mashnu' fi Ma'rifat al-Hadis al-Maudhu' li al-Syaikh 'ala al-Qari al-Harawi, dan adapula yang disusun secara tematis, seperti kitab Tanzih al-Syari'ah al-Marfu'ah 'an al-Ahadis al-Syafiah al-Mawdhu'ah li alKanani.

Apabila hadits yang akan ditakhrij itu termasuk hadis qudsi, maka sumber yang paling mudah untuk mencarinya adalah kitab yang mengumpulkan hadis-hadis qudsi secara tersendiri, seperti kitab Misykat al-Anwar Fima Ruwiya 'An Allah SWT min al-Akhbar li Ibn Arabi. Kitab ini mengumpulkan 101 hadis qudsi lengkap dengan sanadnya.

2) Ditinjau dari segi sanad

Apabila di dalam suatu hadis ada ciri tertentu, misalnya isnad hadis itu mursal, maka hadis itu dapat dicari dalam kitab-kitab yang mengumpulkan hadis-hadis mursal, seperti kitab al-Murasil li Abi Hatim Abd al-Rahman Ibn Muhammad al-Handhali al-Razi, atau mungkin ditemukan seorang rawi yang lemah dalam sanadnya maka dapat dicari dalam kitab Mizan al-I'tidal li al-Dzahabi.

3) Dari segi matan dan sanad

Ada beberapa sifat dan keadaan yang kadang-kadang terdapat pada matan dan kadang-kadang pada sanad, misalnya ada illat (cacat) atau ibham (samar-samar). Untuk mencari hadis semacam itu dapat dilihat dari kitab 
Jurnal Riset Agama, Volume 1, Nomor 1 (April 2021): 233-246

Arif Maulana/Peran Penting Metode Takhrij dalam Studi Kehujjahan Hadis

'Ilal al-Hadis li Ibn Abi Hatim al-Razi, dan al-Mustafad min Mubhamat al-Matn wa al-Isnad li Abi Zar'ah Ahmad Ibn Abd al-Rahim al-'Iraqi (Soetari, 1997).

\section{Tujuan dan Manfaat Takhrij Hadis}

Melalui proses takhrij hadis ini tentunya terdapat tujuan yang ingin dicapai oleh seorang peneliti, karena tujuan merupakan hal paling utama yang ingin diraih dalam proses penelitian. Adapaun beberapa tujuan pokok tersebut, antara lain:

a. Untuk mengetahui keberadaan suatu hadis yang akan di-takhrij apakah benar hadis tersebut terdapat dalam kitab-kitab hadis yang dimaksud atau tidak.

b. Untuk mengetahui sumber otentik hadis-hadis yang diteliti terkait dari mana saja hadis-hadis tersebut didapatkan

c. Untuk mengetahui keragaman sanad dalam satu hadis yang ditemukan di kitab-kitab sumber hadis yang berbeda

d. Untuk mengetahui kualitas suatu hadis dari segi diterima (maqbul) dan ditolak (mardud) (Khon, 2008).

Adapun manfaat dari takhrij hadis dapat dilihat dari adanya usaha takhrij terhadap hadis-hadis Nabi, baik takhrij pada periode awal maupun sesudah hadis-hadis itu resmi dibukukan dalam berbagai kitab hadis, hal ini jelas memberikan banyak manfaat. Di samping menambah pembendaharaan pengetahuan tentang hadis-hadis itu sendiri, tentu saja juga menambah pengetahuan mengenai ilmu hadis.

Salah satu di antara sekian banyak manfaat, yakni melalui usaha takhrij terhadap suatu hadis, seorang pen-takhrij dapat mengumpulkan berbagai sanad yang beragam dari sebuah hadis, dan juga dapat mengumpulkan berbagai perbedaan redaksi matan dari hadis tersebut.

Dengan demikian, usaha takhrij tidak terbatas pada matan saja, akan tetapi juga meliputi takhrij matan hadis dari berbagai kitab induk, kemudian men-takhrij sanad-sanad hadis disertai dengan meneliti biografi dan penilaian terhadap perawinya, men-takhrij lafazh-lafazh yang asing melalui kitab-kitab yang berhubungan dengan lafazh hadis tersebut, mentakhrij peristiwa yang terjadi dalam hadis melalui kitab-kitab yang ditulis untuk itu, dan men-takhrij nama-nama penulis melalui kitab-kitab yang terkait dengan bidangnya (Soetari, 1997).

\section{Kesimpulan}

Dari pembahasan yang telah dipaparkan di atas, dapat diambil kesimpulan bahwa takhrij hadits merupakan hasil dari usaha ulama terdahulu dalam mengembangkan ilmu hadis yang juga merupakan bagian dari khazanah intelektual dan keilmuan yang wajib diteruskan oleh 
Jurnal Riset Agama, Volume 1, Nomor 1 (April 2021): 233-246

Arif Maulana/Peran Penting Metode Takhrij dalam Studi Kehujjahan Hadis

generasi-generasi selanjutnya supaya terus terjaga dan berkembang. Jasa ulama terdahulu begitu besar dalam melakukan ijtihad keilmuan khususnya di bidang ilmu hadis sehingga membuahkan berbagai cabang yang terperinci di dalamnya, salah satunya takhrij hadis. Hal ini dapat dibuktikan dari banyaknya kitab-kitab yang secara khusus berkenaan dengan takhrij hadis. Takhrij hadis dapat disimpulkan sebagai usaha pencarian atau penelusuran suatu hadits dari berbagai kitab sumber yang asli dengan mengungkapkan sanad dan matan hadis secara lengkap yang kemudian diteliti untuk mengetahui kualitas hadis tersebut. Dari sekian metode takhrij yang telah dipaparkan tentunya memiliki keunggulan dan kelemahan tersendiri, yang kemudian metode tersebut saling melengkapi satu sama lain dalam proses penelusuran hadis. Karenanya dalam penggunaan metode takhrij harus memperhatikan teks dan konteks hadis yang akan di-takhrij sehingga menemukan metode yang sesuai. Takhrij hadis telah memberi banyak faedah dan manfaat khususnya bagi bidang ilmu hadis sendiri dan umumnya bagi fan ilmu keislaman yang lain. Melalui takhrij hadis dapat diketahui sumber kitab-kitab hadis yang otentik, keragaman sanad dan matan dalam suatu hadis, mengenal biografi dan keadaan perawinya, serta dapat diketahui pula kualitas hadisnya antara yang maqbul (diterima) dan yang mardud (ditolak) sehingga mendapat kejelasan untuk mengamalkannya.

\section{Daftar Pustaka}

Al-Khatib, M. A. (1975). Al-Sunnah Qabla al-Tadwin. Kairo: Maktabah Wahbah.

Al-Thahhan, M. (1982). Ushul al-Takhrij wa Dirasah al-Asanid. Kairo: Dar alKutub al-Salafiyah.

Ash-Shiddieqy, H. (1967). Pokok-pokok Ilmu Dirayah Hadis. Jakarta: Bulan Bintang.

Ash-Shiddieqy, H. (1980). Sejarah dan Pengantar Ilmu Hadits. Jakarta: Bulan Bintang.

Darmalaksana, W. (2020). Formula Penelitian Pengalaman Kelas Menulis. Jurnal Kelas Menulis UIN Sunan Gunung Djati Bandung.

Fitrah, M., \& Luthfiyah. (2017). Metodologi Penelitian. Sukabumi: CV Jejak. Gunawan, I. (2013). Metode Penelitian Kualitatif. Jakarta: Bumi Aksara.

'Itr, N. (1994). 'Ulum Al-Hadits I (Manhaj An-Naqd Fii 'Uluum Al-Hadits) terj. Mujiyo. Bandung: PT. Remaja Rosdakarya.

Khon, A. M. (2008). Ulumul Hadis. Jakarta: Amzah.

Lubis, R. (2019). Ilmu Takhrij Al-Hadis dalam Sorotan. Universum, 85-96.

Qomarullah, M. (2016). Metode Takhrij Hadis dalam Menakar Hadis Nabi. Jurnal Studi Keislaman El-Ghiroh, 24-34.

Sanusi, A. (2014). Takhrij Hadits. Depok: Madani Publishing.

Soetari, E. (1997). Ilmu Hadits. Bandung: Amal Bakti Press. 
Jurnal Riset Agama, Volume 1, Nomor 1 (April 2021): 233-246

Arif Maulana/Peran Penting Metode Takhrij dalam Studi Kehujjahan Hadis

Halaman ini sengaja dikosongkan 